\author{
Дідух С.M. \\ кандидат економічних наук, доцент \\ кафедра економіки промисловості \\ E-mail: didukhsm@i.ua \\ мініна B.O. \\ Студентка 4 курсу фракультету економіки, бізнесу і контролю \\ E-mail: minina.victory@ukr.net \\ Федорова Т.C. \\ Студентка 4 курсу факультету економіки, бізнесу і контролю \\ Одеська національна академія харчових технологій \\ вул. Канатна, 112, м. Одеса, Україна, 65039 \\ E-mail: fedorova 18 t@ukr.net
}

\title{
ОЦІНКА ОПТИМАЛЬНОЇ СТРУКТУРИ КАПІТАЛУ АГРОХОЛДИНГІВ УКРАЇНИ (KERNEL HOLDING S.A., MHP S.A.)
}

Дана стаття присвячена дослідженню фінансових результатів та особливостей формування капіталу провідних агрохолдингів України в сучасних умовах. Проведено аналіз структури капіталу агрохолдингів України на прикладі Kernel Holding S.A. («Кернел») і MHP S.A. («Миронівський хлібопродукт»). Досліджено динаміку їх фрінансових показників та структуру капіталу із використанням моделі WACC та методу CAPM. Представлено висновки та рекомендації щодо оптимізації структури капіталу Kernel Holding S.A. і MHP S.A. у сучасних умовах.

Ключові слова: агрохолдинг, власний капітал, позиковий капітал, структура капіталу, Kernel Holding S.A., MHP S.A., фінансовий стан, WACC, CAPM.

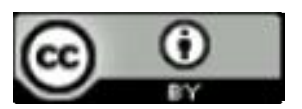

This work is licensed under a Creative Commons Attribution 4.0 International License http://creativecommons.org/licenses/by/4.0/

Постановка проблеми та її зв'язок із важливими науковими та практичними завданнями. В умовах дефіциту фінансово-інвестиційних ресурсів для розвитку та жорсткої кредитної політики НБУ, конкурентною перевагою володіють компанії, які мають доступ до кредитних ресурсів за кордоном. Диспропорція між вартістю капіталу в Україні та на ринках ЄС обумовлена високими ризиками підприємницької діяльності в Україні.

Агрохолдинги України відіграють все більшу роль у розвитку економіки України [1]. Найпотужніші 3 них мають високий кредитний рейтинг і використовують залучені на європейських фондових ринках кошти для розвитку виробництва в Україні. Саме тому в сучасних умовах особливо актуальною $\epsilon$ проблема дослідження структури капіталу українських агрохолдингів, оскільки оптимальна структура капіталу дозволяє раціонально використовувати фінансові ресурси і позитивно впливає на вартість компанії.

Аналіз останніх публікацій по проблемі. Питання формування структури капіталу досліджувалося ще в роботах Модільяні і Міллера [2], J. Williams [3]. Проблемам формування структури капіталу у сучасних економічних умовах присвячені роботи М.А. Зубкова, Д. А. Воронцова [4], В. В. Івашковської, Купріянова С. В. [5], М. М. Калімуліна [6], Т. В. Теплової [7] та інших науковців. Однак оцінка оптимальної структури капіталу агрохол- дингів України як важливого елементу національної економіки перебуває поза увагою вчених-економістів і потребує більш детального дослідження.

Формулювання цілей дослідження. Основною метою даної роботи $є$ визначення оптимальної структури капіталу агрохолдингів України у сучасних економічних умовах за допомогою методики середньозваженої вартості капіталу на прикладі Kernel Holding S.A. («Кернел») і MHP S.A. («Миронівський хлібопродукт»).

Виклад основних результатів та їх обгрунтування. Оптимальною є така структура капіталу, при якій забезпечується якнайкраще співвідношення між рівнем рентабельності власного капіталу та рівнем фінансової стійкості, і таким чином, максимізується вартість підприємства (або його акцій).

Існують такі основні методи визначення оптимальної структури капіталу: метод операційного прибутку, методи EBIT-EPS, метод середньозважених витрат на капітал (WACC). Дані методи дозволяють визначити оптимальну структуру капіталу 3 високою точністю, однак найчастіше при прийнятті рішень щодо фінансування менеджмент керується не тільки питаннями ефективності, але і наочністю варіантів. У зв'язку з цим, у даній роботі ми будемо використовувати метод середньозважених витрат на капітал (WACC).

Метод WACC являє собою метод, при якому оптимальна структура капіталу досягається у точці, 
де максимізується вартість компанії, і середньозважені витрати на капітал є мінімальними. Для визначення WACC в даній статті використовувалася гібридна формула розрахунку, так як вона включає в себе найбільшу кількість факторів:

$$
W A C C=r_{d} * w_{d} *(1-T)+r_{e} * w_{e}
$$

де: $r_{d}$ - вартість позикового капіталу;

$w_{d}$ - питома вага позикового капіталу;

Т - ставка податку на прибуток (18\%);

$r_{e}$ - вартість власного капіталу;

$w_{e}$ - питома вага власного капіталу.

Для розрахунку вартості позикового капіталу була використана наступна формула:

$$
r_{d}=r_{f(u s)}+\text { sovereign }_{\text {spread }}+\text { default }_{\text {spread }},
$$

де: $r_{f(u s)}$ - безризикова ставка дохідності за семирічним держоблігаціями США [8];

sovereign spread - суверенний спред України [9];

default $_{\text {spread }}$ - спред дефолту компанії, який визначається, виходячи з її кредитного рейтингу [10].

Для розрахунку вартості власного капіталу була використана гібридна формула САРМ:

$$
r_{e}=r_{f(u s)}+\beta_{u l} *\left(1+\frac{D *(1-T)}{E} * M R P_{(u s)}+\text { sovereign }_{\text {spread }},\right.
$$

де: $\beta_{u l}$ - коефіцієнт чутливості до ризиків, очищений від впливу боргової навантаження, для тієї ж галузі, що і досліджувана [11];

$M R P_{(u s)}-$ ринкова премія для розвиненого ринку США [12].

Визначення оптимальної структури капіталу компанї МHP S.A. MHP S.A. («Миронівський хлібопродукт») є одним 3 найбільших агропромислових комплексів України з розведення птиці. Компанія має декілька напрямків діяльності: птахівництво та супутні виробництва (виробництво охолодженої курятини, продуктів швидкого приготування), виробництво м'ясних продуктів (свіжої яловичини преміум-класу, фуа-гра, ковбасних виробів і копченостей), рослинництво (вирощування кукурудзи, пшениці, соняшнику, ріпаку), виробництво кормів і соняшникової олії та інші сільськогосподарські операції.

«Миронівський хлібопродукт» - провідна компанія українського ринку курятини, займає близько $35 \%$ ринку курятини і більше $55 \%$ українського ринку промислового виробництва курятини. «Миронівський хлібопродукт» - перша українська агропромислова компанія, чиї цінні папери котуються на основному майданчику Лондонської фондової біржі.

Основні показники діяльності MHP S.A. за 5 років представлені в табл. 1.

Основні показники діяльності MHP S.A. [13]

\begin{tabular}{|c|c|c|c|c|c|c|}
\hline Рік & $\begin{array}{c}\text { Дохід від } \\
\text { реалізції, } \\
\text { тис.дол. }\end{array}$ & $\begin{array}{c}\text { ЕВITDA, } \\
\text { тис.дол. }\end{array}$ & $\begin{array}{c}\text { Операційний } \\
\text { прибуток, } \\
\text { тис.дол. }\end{array}$ & $\begin{array}{c}\text { Чистий прибуток/ } \\
\text { збиток, тис.дол. }\end{array}$ & $\begin{array}{c}\text { ROE, } \\
\%\end{array}$ & ROA,\% \\
\hline 2011 & 1229090 & 401085 & 320744 & 259355 & 28,01 & 20,63 \\
\hline 2012 & 1407522 & 467718 & 380583 & 310916 & 25,94 & 18,80 \\
\hline 2013 & 1496079 & 391070 & 271836 & 162240 & 12,99 & 14,13 \\
\hline 2014 & 1379048 & 555876 & 414975 & -412338 & $-43,61$ & 24,24 \\
\hline 2015 & 1183283 & 459041 & 363915 & -125726 & $-18,69$ & 22,11 \\
\hline
\end{tabular}

У 2011-2013 pp. MHP S.A. отримав чистий прибуток на рівні 160-310 млн. дол.США на рік. У 2014 р. компанія отримала чистий збиток у розмірі 412 млн. дол.США, у 2015 р. - 125 млн. дол.США. Це пов'язано, у першу чергу, із значною девальвацією гривні, а також з забороню на поставку птиці в Мит- ний Союз і припинення роботи птахофабрики «Шахтарська» в Донецькій області та підприємств у окупованій АР Крим.

Вартість власного капіталу MHP S.A. розраховано нами за методом САРМ. Вихідні дані для розрахунку представлені в табл. 2.

\begin{tabular}{|c|c|c|}
\hline \multirow{2}{*}{ Показники } & \multicolumn{2}{|c|}{ Значення } \\
\hline & 2014 & 2015 \\
\hline $\mathrm{R}_{\mathrm{f} \text { (безризикова ставка) }}$ & 2,125 & 2,412 \\
\hline$\beta$ & 0,66 & 0,63 \\
\hline Ринкова премія (Rm-Rf) & 13,9 & 14,6 \\
\hline CRP (премія країни) & 11,25 & 15,01 \\
\hline
\end{tabular}

Таблиця 2

Вихідні дані для розрахунку вартості капіталу MHP S.A. i Kernel Holding S.A. [9-12]

Розрахунок фактичної вартості зобов'язань здійснено нами на основі даних, представлених в звітах про результати господарської діяльності [13]. Ре- зультати розрахунку середньозваженої вартості власного і позикового капіталу за два роки представлено в табл. 3. 
Вартість власного і позикового капіталу МHP S.A. в 2014-2015 pp. [13]

\begin{tabular}{|c|c|c|c|c|c|c|c|}
\hline \multirow[b]{2}{*}{ Показники } & \multicolumn{3}{|c|}{2014} & \multicolumn{3}{|c|}{2015} & \multirow{2}{*}{$\begin{array}{c}\text { Абсолютне } \\
\text { відхилення } \\
\text { структури }\end{array}$} \\
\hline & $\begin{array}{l}\text { Сума, тис. } \\
\text { дол.США }\end{array}$ & $\begin{array}{l}\text { Питома } \\
\text { вага, \% }\end{array}$ & $\begin{array}{c}\text { Середньо- } \\
\text { зважена } \\
\text { вартість } \\
\text { капіталу }\end{array}$ & $\begin{array}{l}\text { Сума, тис. } \\
\text { дол.США }\end{array}$ & $\begin{array}{c}\text { Питома } \\
\text { вага, \% }\end{array}$ & $\begin{array}{c}\text { Середньо- } \\
\text { зважена вар- } \\
\text { тість капіталу }\end{array}$ & \\
\hline Власний капітал & 945522 & 41 & 33,37 & 672849 & 32 & 42,65 & \\
\hline $\begin{array}{l}\text { Довгострокові зо- } \\
\text { бов'язання }\end{array}$ & 919701 & 40 & 7,3 & 1029483 & 50 & 7,77 & -9 \\
\hline $\begin{array}{l}\text { Короткострокові } \\
\text { зобов'язання }\end{array}$ & 428265 & 19 & 6,84 & 373401 & 18 & 5,22 & 10 \\
\hline Усього зобов'язань & 1347966 & 59 & 7,15 & 1402884 & 68 & 7,09 & -1 \\
\hline Усього & 2293488 & 100 & 17,14 & 2075733 & 100 & 17,6 & 9 \\
\hline
\end{tabular}

Капітал MHP S.A. у 2015 р. зменшився на 217755 тис. дол.США. Частка власного капіталу у 2015 р. зменшилась на 9\%, тоді як сума зобов'язань зросла на 54918 тис. дол, США. Це сталося за рахунок збільшення довгострокових зобов'язань на 109782 тис. дол. США та зменшення короткострокових зобов' язань на 54864 тис. дол. США.
Дані розрахунків свідчать про велику різницю між вартістю власного капіталу (33\% і 43\%) та позикового (7\%). За рахунок цього середньозважена вартість всього капіталу MHP S.A. була на рівні $17,14-17,6 \%$.

Для визначення оптимальної структури капіталу, необхідно звернутися до кредитного рейтингу в залежності від боргового навантаження (табл. 4).

Таблиця 4

Кредитний рейтинг в залежності від боргового навантаження [9]

\begin{tabular}{|c|c|c|c|c|c|c|c|c|c|c|}
\hline D/(D+E) & 0 & 5 & 10 & 15 & 20 & 25 & 30 & 35 & 40 & 45 \\
\hline Raiting & AAA & AA+ & AA & AA- & A+ & A & A- & BBB+ & BBB & BBB- \\
\hline \multicolumn{1}{|l|}{} \\
\hline D/(D+E) & 50 & 55 & 60 & 65 & 70 & 75 & 80 & 85 & 90 \\
\hline Raiting & BB+ & BB & BB- & B+ & B & B- & CCC+ & CCC & CCC- \\
\hline
\end{tabular}

Спред дефолту залежить від кредитного

рейтингу (табл. 5).

Таблиця 5

Спред дефолту в залежності від кредитного рейтингу [14]

\begin{tabular}{|c|c|c|c|c|c|c|c|c|c|c|}
\hline Raiting & $\mathrm{AAA}$ & $\mathrm{AA}+$ & $\mathrm{AA}$ & $\mathrm{AA}-$ & $\mathrm{A}+$ & $\mathrm{A}$ & $\mathrm{A}-$ & $\mathrm{BBB}+$ & $\mathrm{BBB}$ & $\mathrm{BBB}-$ \\
\hline default_spread & 0,4 & 0,55 & 0,7 & 0,775 & 0,85 & 1 & 1,3 & 1,65 & 2 & 2,5 \\
\hline \multicolumn{1}{|c|}{} \\
\hline Raiting & $\mathrm{BB}+$ & $\mathrm{BB}$ & $\mathrm{BB}-$ & $\mathrm{B}+$ & $\mathrm{B}$ & $\mathrm{B}-$ & $\mathrm{CCC}+$ & $\mathrm{CCC}$ & CCC- \\
\hline default_spread & 3 & 4 & 4,75 & 5,5 & 6,5 & 7,25 & 8 & 9 & 9,8 \\
\hline
\end{tabular}

На підставі різних показників боргового навантаження і розрахованих для кожної з них прибутковості на власний і позиковий капітал, нами визначено показник WACC (табл. 6 і 7). Для цього нами було розраховано вартість власного капіталу компанії за 2014-2015 рр. за допомогою представленої методики.

Таблиця 6

Розрахунок показника WACC MHP S.A. за 2014 р.*

\begin{tabular}{|c|c|c|c|c|c|c|c|}
\hline Wd & We & Raiting & default_spread & rd & re & D/E & WACC \\
\hline 0 & 100 & AAA & 0,4 & 2,950 & 22,55 & 0,00 & 22,55 \\
\hline 5 & 95 & AA+ & 0,55 & 3,100 & 22,94 & 0,05 & 21,92 \\
\hline 10 & 90 & AA & 0,7 & 3,250 & 23,38 & 0,11 & 21,31 \\
\hline 15 & 85 & AA- & 0,78 & 3,325 & 23,88 & 0,18 & 20,70 \\
\hline 20 & 80 & A+ & 0,85 & 3,400 & 24,43 & 0,25 & 20,10 \\
\hline 25 & 75 & A & 1,00 & 3,550 & 25,06 & 0,33 & 19,52 \\
\hline
\end{tabular}


Продовження табл.6

\begin{tabular}{|c|c|c|c|c|c|c|c|}
\hline Wd & We & Raiting & default_spread & rd & re & D/E & WACC \\
\hline 30 & 70 & A- & 1,3 & 3,850 & 25,77 & 0,43 & 18,99 \\
\hline 35 & 65 & BBB+ & 1,65 & 4,200 & 26,60 & 0,54 & 18,50 \\
\hline 40 & 60 & BBB & 2 & 4,550 & 27,56 & 0,67 & 18,03 \\
\hline 45 & 55 & BBB- & 2,5 & 5,050 & 28,70 & 0,82 & 17,65 \\
\hline 50 & 50 & BB+ & 3 & 5,550 & 30,07 & 1,00 & 17,31 \\
\hline 55 & 45 & BB & 4 & 6,550 & 31,74 & 1,22 & 17,24 \\
\hline 59 & 41 & BB- & 4,6 & 7,150 & 33,37 & 1,44 & 17,14 \\
\hline 60 & 40 & BB- & 4,75 & 7,300 & 33,83 & 1,50 & 17,12 \\
\hline 65 & 35 & B+ & 5,5 & 8,050 & 36,52 & 1,86 & 17,07 \\
\hline 70 & 30 & B & 6,5 & 9,050 & 40,10 & 2,33 & 17,23 \\
\hline 75 & 25 & B- & 7,25 & 9,800 & 45,12 & 3,00 & 17,31 \\
\hline 80 & 20 & CCC+ & 8 & 10,550 & 52,64 & 4,00 & 17,45 \\
\hline 85 & 15 & CCC & 9 & 11,550 & 65,18 & 5,67 & 17,83 \\
\hline 90 & 10 & CCC- & 9,8 & 12,350 & 90,25 & 9,00 & 18,14 \\
\hline
\end{tabular}

* авторська розробка

Згідно з розрахунками, WACC приймає мінімальне значення 17,07 при структурі капіталу: 65\% власного капіталу і 35\% позикового капіталу. Саме таку структуру слід вважати оптимальною. Рівень боргового навантаження у 2014 р. був 59\%, а WACC дорівнював 17,14. Таким чином структура капіталу MHP S.A. у 2014 р. була близькою до оптимальної.
У 2015 р., згідно з розрахунками, оптимальною для MHP S.A. була структура капіталу $80 \%$ позикового і $20 \%$ власного (WACC 17,29). Оскільки фактичний рівень боргового навантаження дорівнював $68 \%$ (WACC 17,75), то MHP S.A. доцільно розглядати варіант збільшення частки позикового капіталу для досягнення його оптимальної середньозваженої вартості.

Таблиця 7

Розрахунок показника WACC MHP S.A. за 2015 р. *

\begin{tabular}{|c|c|c|c|c|c|c|c|}
\hline Wd & We & Raiting & default_spread & rd & re & D/E & WACC \\
\hline 0 & 100 & AAA & 0,4 & 1,45 & 27,25 & 0 & 27,25 \\
\hline 5 & 95 & AA+ & 0,55 & 1,60 & 41,62 & 0,05 & 39,60 \\
\hline 10 & 90 & AA & 0,7 & 1,75 & 42,47 & 0,11 & 38,36 \\
\hline 15 & 85 & AA- & 0,78 & 1,83 & 27,95 & 0,18 & 23,98 \\
\hline 20 & 80 & A+ & 0,85 & 1,90 & 28,51 & 0,25 & 23,12 \\
\hline 25 & 75 & A & 1,00 & 2,05 & 29,13 & 0,33 & 22,27 \\
\hline 30 & 70 & A- & 1,3 & 2,35 & 29,85 & 0,43 & 21,47 \\
\hline 35 & 65 & BВB+ & 1,65 & 2,70 & 30,68 & 0,54 & 20,72 \\
\hline 40 & 60 & BВB & 2 & 3,05 & 31,65 & 0,67 & 19,99 \\
\hline 45 & 55 & BВB- & 2,5 & 3,55 & 32,79 & 0,82 & 19,35 \\
\hline 50 & 50 & BВ+ & 3 & 4,05 & 34,16 & 1,00 & 18,74 \\
\hline 55 & 45 & BВ & 4 & 5,05 & 35,84 & 1,22 & 18,40 \\
\hline 60 & 40 & BВ- & 4,75 & 5,80 & 37,93 & 1,50 & 18,03 \\
\hline 65 & 35 & B+ & 5,5 & 6,55 & 40,63 & 1,86 & 17,71 \\
\hline 68 & 32 & B & 6,3 & 7,35 & 42,65 & 2,13 & 17,75 \\
\hline 70 & 30 & B & 6,5 & 7,55 & 44,22 & 2,33 & 17,60 \\
\hline 75 & 25 & B- & 7,25 & 8,30 & 49,25 & 3,00 & 17,42 \\
\hline 80 & 20 & CCC+ & 8 & 9,05 & 56,79 & 4,00 & 17,29 \\
\hline 85 & 15 & CCC & 9 & 10,05 & 69,36 & 5,67 & 17,41 \\
\hline 90 & 10 & CCC- & 9,8 & 10,85 & 94,50 & 9,00 & 17,46 \\
\hline
\end{tabular}

Визначення оптимальної структури капіталу компанї «Kernel». Kernel Holding S.A. («Kernel») провідна диверсифікована агропромислова компанія в Чорноморському регіоні. Експортуючи щорічно близько 7 мільйонів тонн сільськогосподарської про- дукції, «Kernel»є найбільшим постачальником соняшникової олії і шроту на міжнародний ринок і одним 3 найбільших експортерів зернових 3 чорноморського регіону. 
Діяльність компанії зосереджена в таких бізнес-сегментах: виробництво соняшникової олії; експорт соняшникової олії і зернових культур; дистрибуція бутильованої олії на внутрішньому ринку; надання послуг з перевалки зернових вантажів в порту Іллічівська та портах Миколаєва; зберігання зернових і олійних культур на внутрішніх елеваторах; агровиробництво.

Компанія випускає продукцію під торговими марками «Щедрий Дар», «Стожар», «Чумак Домашня», «Чумак Золота». На частку компанії припадає близько $8 \%$ світового виробництва соняшникової олії. Свою продукцію «Kernel» поставляє в більш ніж 60 країн світу, серед основних ринків збуту - Індія, країни Свросоюзу, Сгипет і Туреччина. Переробні потужності «Kernel» складають 3 млн. т насіння соняшнику на рік, що дозволяє отримати 1,3 млн. т соняшникової олії і близько 1,2 млн. т соняшникової шроту.

Основні фінансові результати «Kernel» за 5 років надані в табл. 8 .

Основні показники діяльності Kernel Holding S.A. [15]

\begin{tabular}{|c|c|c|c|c|c|c|}
\hline Рік & $\begin{array}{c}\text { Дохід від реалі- } \\
\text { зції, тис.дол. }\end{array}$ & $\begin{array}{c}\text { ЕВІТDА, } \\
\text { тис.дол. }\end{array}$ & $\begin{array}{c}\text { Операційний } \\
\text { прибуток, } \\
\text { тис.дол. }\end{array}$ & $\begin{array}{c}\text { Чистий прибуток/ } \\
\text { збиток, тис.дол. }\end{array}$ & ROE,\% & ROA,\% \\
\hline 2011 & 2071,80 & 318830 & 257297 & 210782 & 12,16 & 15,06 \\
\hline 2012 & 2796,80 & 287560 & 200891 & 105253 & 8,49 & 12,15 \\
\hline 2013 & 2393,30 & 223065 & 128717 & -107406 & 6,71 & 11,62 \\
\hline 2014 & 2329,50 & 396576 & 335557 & 95533 & 22,90 & 27,06 \\
\hline 2015 & 1988,50 & 346374 & 287190 & 226844 & 19,03 & 22,95 \\
\hline
\end{tabular}

Діяльність «Kernel» є прибутковою - чистий прибуток на рівні 95-226 млн. дол. США на рік, за винятком 2013 р., коли чистий збиток склав 107,4 млн. дол. США через несприятливу політичну ситуацію в Україні, падіння цін на сировинні товари і девальвацію гривні. У 2014-2015 рр. компанія змогла виправити ситуацію і суттєво покращити фінансові результати. Вартість власного капіталу «Kernel» за 2014-2015 рр. нами розраховано за методом САРМ (табл. 9) за вихідними даними табл. 2.

Таблиця 9

Середньозважена вартість власного і позикового капіталу Kernel Holding S.A. в 2014-2015 pp. [15]

\begin{tabular}{|c|c|c|c|c|c|c|c|}
\hline \multirow[b]{2}{*}{ Показники } & \multicolumn{3}{|c|}{2014} & \multicolumn{3}{|c|}{2015} & \multirow[b]{2}{*}{$\begin{array}{c}\text { Абсолютне } \\
\text { відхилення } \\
\text { структури }\end{array}$} \\
\hline & $\begin{array}{c}\text { Сума, } \\
\text { тис.дол }\end{array}$ & $\begin{array}{l}\text { Питома } \\
\text { вага, \% }\end{array}$ & $\begin{array}{c}\text { Середньо- } \\
\text { зважена } \\
\text { вартість } \\
\text { капіталу }\end{array}$ & $\begin{array}{c}\text { Сума, } \\
\text { тис.дол }\end{array}$ & $\begin{array}{c}\text { Питома } \\
\text { вага, \% }\end{array}$ & $\begin{array}{c}\text { Середньо- } \\
\text { зважена } \\
\text { вартість } \\
\text { капіталу }\end{array}$ & \\
\hline Власний капітал & 890844 & 61 & 27,4 & 997055 & 66 & 30,5 & 5 \\
\hline $\begin{array}{l}\text { Довгострокові } \\
\text { зобов' язання }\end{array}$ & 116670 & 8 & 4,36 & 138995 & 9 & 4,47 & 1 \\
\hline $\begin{array}{l}\text { Короткострокові } \\
\text { зобов'язання }\end{array}$ & 458104 & 31 & 5,52 & 373305 & 25 & 4,61 & -6 \\
\hline Усього зобов'язань & 574774 & 39 & 5,28 & 512300 & 34 & 4,57 & -5 \\
\hline Баланс & 1465618 & 100 & 18,41 & 1509355 & 100 & 21,4 & 0 \\
\hline
\end{tabular}

Короткострокові зобов'язання при цьому зросли на 84799 тис. дол. США (на 6\%), а довгострокові - на 22325 (на 1\%). Більш дорогий власний капітал (27\% у 2014 р. і $30 \%$ у 2015 р.) компенсується дешевим позиковим (5\% і 4,5\%). Саме тому середньо- зважена вартість капіталу «Kernel» 2014-2015pp. була на рівні $18-20 \%$.

На підставі показників боргового навантаження і розрахованих для кожної з них прибутковості на власний і позиковий капітал, нами визначено показник WACC (табл. 10 і 11).

Таблиця 10

Розрахунок показника WACC Kernel Holding S.A. 392014 p.*

\begin{tabular}{|c|c|c|c|c|c|c|c|}
\hline Wd & We & Raiting & default_spread & Rd & Re & D/E & WACC \\
\hline 10 & 90 & AA & 0,7 & 4,080 & 23,38 & 0,11 & 21,38 \\
\hline 15 & 85 & AA- & 0,7750 & 4,155 & 23,88 & 0,18 & 20,81 \\
\hline 20 & 80 & A+ & 0,85 & 4,230 & 24,43 & 0,25 & 20,24 \\
\hline
\end{tabular}


Продовження табл.10

\begin{tabular}{|c|c|c|c|c|c|c|c|}
\hline Wd & We & Raiting & default_spread & Rd & Re & D/E & WACC \\
\hline 25 & 75 & A & 1,00 & 4,380 & 25,06 & 0,33 & 19,69 \\
\hline 30 & 70 & A- & 1,3 & 4,680 & 25,77 & 0,43 & 19,19 \\
\hline 35 & 65 & BBB+ & 1,5 & 4,880 & 26,60 & 0,54 & 18,69 \\
\hline 39 & 61 & BBB+ & 1,9 & 5,280 & 27,36 & 0,64 & 18,38 \\
\hline 40 & 60 & BBB & 2 & 5,380 & 27,56 & 0,67 & 18,30 \\
\hline 45 & 55 & BBB- & 2,5 & 5,880 & 28,70 & 0,82 & 17,96 \\
\hline 50 & 50 & BB+ & 3 & 6,380 & 30,07 & 1,00 & 17,65 \\
\hline 55 & 45 & BB & 4 & 7,380 & 31,74 & 1,22 & 17,61 \\
\hline 60 & 40 & BB- & 4,750 & 8,130 & 33,83 & 1,50 & 17,53 \\
\hline 65 & 35 & B+ & 5,5 & 8,880 & 36,52 & 1,86 & 17,51 \\
\hline 70 & 30 & B & 6,5 & 9,880 & 40,10 & 2,33 & 17,70 \\
\hline 75 & 25 & B- & 7,25 & 10,630 & 45,12 & 3,00 & 17,82 \\
\hline 80 & 20 & CCC+ & 8 & 11,380 & 52,64 & 4,00 & 17,99 \\
\hline 85 & 15 & CCC & 9 & 12,380 & 65,18 & 5,67 & 18,41 \\
\hline 90 & 10 & CCC- & 9,8 & 13,180 & 90,25 & 9,00 & 18,75 \\
\hline
\end{tabular}

* авторська розробка

У 2014 р. оптимальною була структура капіталу при співвідношенні $65 \%$ позикового капіталу і $35 \%$ власного, так як при цьому спостерігалось мінімальне значення WACC (17,51\%). Фактично у 2014 p. «Kernel» мав $39 \%$ позикового капіталу i WACC $18,38 \%$. Тобто структура капіталу не була оптимальною.
У 2015 р. мінімальне значення WACC $(18,57 \%)$ було при частці позикового капіталу у $80 \%$. Оскільки фактичний рівень боргового навантаження дорівнює $34 \%$ i WACC 21,41, то Kernel може залучати додатковий позиковий капітал і це позитивно вплине на загальну вартість капіталу.

Таблиця 11

Розрахунок показника WACC Kernel за 2015 р.*

\begin{tabular}{|c|c|c|c|c|c|c|c|}
\hline Wd & We & Raiting & default_spread & Rd & Re & D/E & WACC \\
\hline 10 & 90 & AA & 0,7 & 3,690 & 27,46 & 0,11 & 25,01 \\
\hline 15 & 85 & AA- & 0,7750 & 3,765 & 27,95 & 0,18 & 24,22 \\
\hline 20 & 80 & A+ & 0,85 & 3,840 & 28,51 & 0,25 & 23,43 \\
\hline 25 & 75 & A & 1,00 & 3,990 & 29,13 & 0,33 & 22,67 \\
\hline 30 & 70 & A- & 1,3 & 4,290 & 29,85 & 0,43 & 21,95 \\
\hline 34 & 66 & BBB+ & 1,58 & 4,570 & 30,51 & 0,54 & 21,41 \\
\hline 35 & 65 & BBB+ & 1,65 & 4,640 & 30,68 & 0,64 & 21,27 \\
\hline 40 & 60 & BBB & 2 & 4,990 & 31,65 & 0,67 & 20,63 \\
\hline 45 & 55 & BBB- & 2,5 & 5,490 & 32,79 & 0,82 & 20,06 \\
\hline 50 & 50 & BB+ & 3 & 5,990 & 34,16 & 1,00 & 19,54 \\
\hline 55 & 45 & BB & 4 & 6,990 & 35,84 & 1,22 & 19,28 \\
\hline 60 & 40 & BB- & 4,750 & 7,740 & 37,93 & 1,50 & 18,98 \\
\hline 65 & 35 & B+ & 5,5 & 8,490 & 40,63 & 1,86 & 18,74 \\
\hline 70 & 30 & B & 6,5 & 9,490 & 44,22 & 2,33 & 18,71 \\
\hline 75 & 25 & B- & 7,25 & 10,240 & 49,25 & 3,00 & 18,61 \\
\hline 80 & 20 & CCC+ & 8 & 10,990 & 56,79 & 4,00 & 18,57 \\
\hline 85 & 15 & CCC & 9 & 11,990 & 69,36 & 5,67 & 18,76 \\
\hline 90 & 10 & CCC- & 9,8 & 12,790 & 94,50 & 9,00 & 18,89 \\
\hline
\end{tabular}

* авторська розробка

Висновки та перспективи подалыших досліджень. Капітал агрохолдингів України сформований під впливом диспропорції - високої вартості власного капіталу та низької вартості позикового капіталу на європейських фондових ринках. Висока вартість власного капіталу обумовлена кредитним рейтингом України та високим ризиком підприємницької діяльності в країні.

Загалом структура капіталу i «МХП», i «Kernel» не $\epsilon$ оптимальною, але прагне до неї. Менеджмент компаній може збільшувати частку позикового капіталу, так як його вартість дешевша, ніж вар- 
тість власного капіталу. Але слід враховувати, що за рахунок збільшення зобов'язань збільшується ризик неплатоспроможності, а це в свою чергу може призвести до банкрутства компаній. Таким чином, слід приймати до уваги можливі наслідки від збільшення частки позикового капіталу.

У сучасних економічних умовах Kernel Holding S.A. та MHP S.A. активно розвиваються шляхом збільшення масштабів виробництва, завоювання нових ринків збуту. Тому при формуванні капіталу обидві компанії роблять вибір на користь зменшення вартості капіталу за рахунок збільшення части позико- вих коштів, збільшуючи при цьому ризик втрати платоспроможності. У середньостроковій перспективі при підвищенні кредитного рейтингу України слід очікувати зменшення вартості власного капіталу агрохолдингів, що має вплинути на оптимальну структуру їх капіталу.

Перспективи подальших досліджень полягають у оцінці оптимальної структури капіталу інших агрохолдингів та вертикально інтегрованих компаній України, аналізі динаміки зміни вартості власного та позикового капіталу агрохолдингів.

\section{Література}

1. Дідух С.М. Оцінка фінансового стану та динаміки розвитку агрохолдингів України / С.М. Дідух // Економіка харчової промисловості. - 2015. - С. 41-49.

2. Modigliani F. The Cost of Capital, Corporation Finance and the Theory of Investment / F. Modigliani, M. H. Miller. // Amer. Econ. Rev.. - 1958. - C. 261-297.

3. Williams J. The Theory of Investment Value / J. Williams. - Cambridge: MA: Harvard University Press, 1938. $-638 \mathrm{c}$.

4. Воронцов Д. А. Оценка оптимальной структуры капитала компаний MD MEDICAL GROUP и X5 RETAIL GROUP / Д. А. Воронцов, Н. А. Зубков. // Корпаративные финансы. - 2014. - №1(29). - С. 99-107.

5. Ивашковская И. В. Структура капитала: резервы создания стоимости для собственников компании / И. В. Ивашковская, А. С. Куприянов // Управление компанией. - 2005. - №2. - С. 1-5.

6. Определение оптимальной структуры капитала российских компаний на примере ОАО «Магнит» и ОАО «Лукойл» / [М. М. Калимулин, Н. А. Меньшова, И. М. Усок та ін.] // Корпоративные финансы. - 2014. - №2. - C. 59-76.

7. Теплова Т. В. Инвестиции / Т. В. Теплова. - Москва: Юрайт, 2011. - 724 с.

8. U.S. 7-Year Bond Yield [Електронний pecypc]. - 2017. - Режим доступу до ресурсу: https://www.investing.com/rates-bonds/u.s.-7-year-bond-yield.

9. The Sovereign Spread of Ukraine [Електронний ресурс] - Режим доступу до ресурсу: http://pages.stern.nyu.edu/ adamodar/.

10. The Trading Economics credit rating [Електронний ресурс]. - Режим доступу до ресурсу: http://www.tradingeconomics.com/country-list/rating.

11. Коефіцієнт чутливості до ризиків [Електронний ресурс]. - Режим доступу до ресурсу: http://pages.stern.nyu.edu/ adamodar/.

12. The market premium for the US market. [Електронний ресурс]. - Режим доступу до ресурсу: http://corporate.morningstar.com/ib/documents/targetmaturity/ Ibbotson-Target-Risk-Report-Q1-2014.pdf.

13. Консолідований звіт менеджменту Ради Директорів MHP S.A. за 2015 p. [Електронний ресурс]. - Режим доступу до ресурсу: http://www.mhp.com.ua/library/file/mhp-sa-fs-2015-ukrfinal_1.pdf.

14. Spread of default based on the credit rating [Електронний ресурс]. - Режим доступу до ресурсу: http://www.pages.stern.nyu.edu/ adamodar/.

15. Kernel Holding S.A. Annual Report and Accounts 30 June 2016 [Електронний ресурс]. - Режим доступу до ресурcy: http://www.kernel.ua/media/uploads/ibrary/16/12/KERNEL_FY2016_Annual_Report_2.pdf. 


\author{
Дидух С.M. \\ кандидат экономических наук, доцент \\ кафедра экономики промышленности \\ E-mail: didukhsm@i.ua \\ Минина B.A. \\ Студентка 4 курса фракультета экономики, бизнеса и контроля \\ E-mail: minina.victory@ukr.net \\ Федорова Т.C. \\ Студентка 4 курса фракультета экономики, бизнеса и контроля \\ Одесская национальная академия пищевых технологий \\ ул. Канатная, 112, г. Одесса, Украина, 65039 \\ E-mail: fedorova 18 t@ukr.net
}

\title{
ОЦЕНКА ОПТИМАЛЬНОЙ СТРУКТУРЫ КАПИТАЛА АГРОХОЛДИНГОВ УКРАИНЫ (KERNEL HOLDING S.A., MHP S.A.)
}

В статье проведено исследование финансовых результатов и выявлены особенности формирования капитала ведущих агрохолдингов Украины в современных условиях на примере MHP S.A. i Kernel Holding S.A. MHP S.A. является одним из крупнейших агрохолдингов Украины, основные направления деятельности которого птицеводство, производство мясных продуктов, растениеводство, производство кормов и подсолнечного масла и другие сельскохозяйственные операции. Деятельность Kernel Holding S.A. сосредоточена в таких сегментах: производство подсолнечного масла; экспорт подсолнечного масла и зерновых культур; дистрибуция бутилированного масла на внутреннем рынке; предоставление услуг по перевалке зерновых грузов; хранения зерновых и масличных культур; агропроизводство.

В условиях нестабильной экономической ситуации актуальна проблема определения оптимальной структуры капитала, поскольку она непосредственно влияет на эфрфективность деятельности и стоимость предприятий. Указано, что оптимальной является структура капитала компании, при которой обеспечивается наилучшее соотношение между уровнем рентабельности собственного капитала и уровнем фринансовой устойчивости, и таким образом, максимизирует стоимость предприятия. В статье проанализированы основные финансовые показатели хозяйственной деятельности агрохолдингов за 5 лет: выручка от реализации, EBITDA, операционная прибыль, а также экономическая рентабельность и рентабельность активов.

Использована модель WACC, которая дала возможность рассчитать стоимость капитала при различном уровне долговой нагрузки и найти оптимальное соотношение собственного и заемного капитала. Проанализирована структура капитала Kernel Holding S.A. и MHP S.A. за 2014-2015 гг. и определено, что развитие этих компаний происходит за счет привлечения заемного капитала, стоимость которого значительно ниже стоимости собственного капитала, рассчитанного с помощью гибридной формулы САРМ. Высокая стоимость собственного капитала обусловлена высокими значениями рыночной премии (Rm-Rf) и премии страны CRP. Сформулированы рекомендации относительно дальнейшей оптимизации структуры капитала компаний.

Ключевые слова: агрохолдинг, собственный капитал, заемный капитал, структура капитала, Kernel Holding S.A., MHP S.A., фринансовое состояние, WACC, CAPM.

Didukh S.

Ph.D., Associate Professor

Department of Industrial Economics

E-mail: didukhsm@i.ua

Minina V.

The student of the fourth grade of Economy, Business and Control Faculty E-mail: minina.victory@ukr.net

Fedorova T.

The student of the fourth grade of Economy, Business and Control Faculty Odessa National Academy of Food Technologies

Kanatna str., 112, Odessa, Ukraine, 65039

E-mail: fedorova 18 t@ukr.net

\section{ASSESSMENT OF THE OPTIMAL CAPITAL STRUCTURE OF AGROHOLDINGS OF UKRAINE (KERNEL HOLDING S. A., MHP S. A.)}

The article studies financial results and identifies the features of the formation of the capital of the leading agroholdings of Ukraine in modern conditions using the example of MHP S.A. I Kernel Holding S.A. MHP S.A. is one of the largest agro-shelters in Ukraine, the main activities of which are poultry farming, meat 
production, crop production, feed and sunflower oil production and other agricultural operations. The activity of Kernel Holding S.A. is concentrated in such segments: sunflower oil production; export of sunflower oil and cereals; distribution of bottled oil; in the home market provision of services for transshipment of grain cargo; storage of grain and oilseeds; agroproduction.

In the conditions of an unstable economic situation, the problem of determining the optimal structure of capital is urgent, as it directly affects the efficiency of activity and the value of enterprises. It is indicated that the optimal structure is the company's capital structure, which provides an optimal balance between the level of return on equity and the level of financial stability, and thus maximizes the value of the enterprise. The article analyzes the main financial indicators of economic activities of agroholdings for 5 years: sales proceeds, EBITDA, operating profit, as well as economic profitability and profitability of assets.

The WACC model was used, which made it possible to calculate the cost of capital at various levels of debt load and to find the optimal ratio of own and borrowed capital. The capital structure of Kernel Holding S.A. and MHP S.A. is analyzed for 2014-2015 years. It is determined that the development of these companies occurs at the expense of borrowed capital, the cost of which is much lower than the cost of equity, calculated using the hybrid formula CAPM. The high cost of equity is due to high market premiums (Rm-Rf) and the country's CRP premium. Recommendations are formulated for further optimization of the capital structure of companies.

Keywords: agroholding, equity, debt capital, capital structure, Kernel Holding S. A., MHP S. A., financial condition, WACC, CAPM.

\section{References}

1. Didukh, S. M. (2015). Otsinka finansovoho stanu ta dynamiky rozvytku ahrokholdynhiv Ukrainy. Ekonomika kharchovoi promyslovosti, 41-45.

2. Modigliani , F., \& Miller, M. H. (1958). The Cost of Capital, Corporation Finance and the Theory of Investment . Amer. Econ. Rev., 261-297.

3. Williams, J. (1938). The Theory of Investment Value. Cambridge: MA: Harvard University Press.

4. Vorontsov, D. A., \& Zubkov, N. A. (2014). Otsenka optymalnoi strukturb kapytala kompanyi MD MEDICAL GROUP y X5 RETAIL GROUP . Korparatyvnыe fynansы, 1(29), 99-107.

5. Yvashkovskaia , Y. V., \& Kupryianov, A. S. (2005). Struktura kapytala: rezervb sozdanyia stoymosty dlia sobstvennykov kompanyy . Upravlenye kompanyei, 2, 1-5.

6. Kalymulyn, M. M., Menshova, N. A., \& Usok, Y. M. (2014). Opredelenye optymalnoi strukturb kapytala rossyiskykh kompanyi na prymere OAO «Mahnyt» y OAO «Lukoil». Korporatyvnыe fynansы, 2, 59-76.

7. Teplova, T. V. (2011). Ynvestytsyy. Moskva: Yurait.

8. U.S. 7-Year Bond Yield. Retrieved August 23, 2017, from www.investing.com/rates-bonds/u.s.-7-year-bond-

yield

9. The Sovereign Spread of Ukraine . Retrieved August 23, 2017, from http://pages.stern.nyu.edu/ adamodar/

10. The Trading Economics credit rating. Retrieved August 23, 2017, from http://www.tradingeconomics.com/country-list/rating

11. Koefitsiient chutlyvosti do ryzykiv . Retrieved August 23, 2017, from http://pages.stern.nyu.edu/ adamodar/

12. The market premium for the US market. (n.d.). Retrieved August 23, 2017, from http://corporate.morningstar.com/ib/documents/targetmaturity/ Ibbotson-Target-Risk-Report-Q1-2014.pdf.The market premium for the US market. Retrieved August 23, 2017, from http://corporate.morningstar.com/ib/documents/targetmaturity/ Ibbotson-Target-Risk-Report-Q1-2014.pdf.

13. Konsolidovanyi zvit menedzhmentu Rady Dyrektoriv MHP S.A. za 2015 r. Retrieved August 23, 2017, from http://www.mhp.com.ua/library/file/mhp-sa-fs-2015-ukr-final_1.pdf.

14. Spread of default based on the credit rating . (n.d.). Retrieved August 23, 2017, from http://www.pages.stern.nyu.edu/ adamodar/

15. Kernel Holding S.A. Annual Report and Accounts 30 June 2016. Retrieved August 23, 2017, from http://www.kernel.ua/media/uploads/library/16/12/KERNEL_FY2016_Annual_Report_2.pdf 